\title{
Rekonstruksi pemulihan kinerja pemasaran berbasis pemberdayaan pada pelaku usaha mikro kecil di Indonesia
}

\author{
Febrianur Ibnu Fitroh Sukono Putra* \\ Fakultas Ekonomi dan Bisnis, Universitas Dian Nuswantoro \\ Jl. Nakula 1-5, Kec. Semarang Tengah, Kota Semarang, Jawa Tengah, 50131, Indonesia \\ fbr10@dsn.dinus.ac.id \\ Risanda Alirastra Budiantoro \\ Fakultas Ekonomi dan Bisnis, Universitas Dian Nuswantoro \\ J1. Nakula 1-5, Kec. Semarang Tengah, Kota Semarang, Jawa Tengah, 50131, Indonesia \\ risanda.abe@gmail.com \\ Awanis Linati Haziroh \\ Fakultas Ekonomi dan Bisnis, Universitas Dian Nuswantoro \\ Jl. Nakula 1-5, Kec. Semarang Tengah, Kota Semarang, Jawa Tengah, 50131, Indonesia \\ awanislinati@dsn.dinus.ac.id \\ *Penulis Korespondensi
}

Submitted: Sept 26, 2021; Reviewed: Oct 2, 2021; Accepted: Nov 12, 2021

\begin{abstract}
The Covid-19 pandemic has made most economic sectors, especially micro and small enterprises, stagnant and even bankrupt. This situation is what makes micro and small business enterprises change their sales strategy through digitalization schemes. The Covid-19 pandemic has indirectly prompted new changes in Indonesia's business style. Social media and marketplaces can become a new concept to make it easier for micro and small business actors to get more comprehensive marketing access. This study aims to initiate an ideal digital marketing adoption model for micro and small enterprise to restore economic conditions to their original state. The research method is an exploratory qualitative approach using primary data obtained from observations and interviews. The sampling technique used purposive sampling with the criteria of the sources being micro and small business actors assisted by the Department of Cooperatives and SMEs of Semarang, Surakarta, Grobogan, Pemalang, Purworejo. The flow of research analysis is data collection, data reduction, data presentation, and concluding. The results of this study indicate two alternative solution models, including training and startup development and training and scaleup development. The urgency of this research allows the government to carry out single submission online program management to minimize errors and monitor program progress. This solution model is expected to be a role model based on ta'awun (mutual relations) for other provincial governments in empowering micro and small business actors to become more optimal based on appropriate technology.
\end{abstract}

Keywords: digital entrepreneurship; digital marketing; economic recovery; empowerment; micro and small enterprises 
Abstrak: Pandemi Covid-19 telah membuat mayoritas sektor ekonomi, terutama usaha mikro kecil, menjadi stagnan bahkan menurun sehingga banyak yang berakhir pada kebangkrutan. Hal inilah yang membuat pelaku usaha mikro kecil mengubah strategi penjualan melalui skema digitalisasi. Meski begitu, pandemi Covid-19 secara tidak langsung telah mendorong perubahan baru dalam langgam bisnis Indonesia. Media sosial dan marketplace dapat menjadi sebuah konsep baru untuk mempermudah pelaku usaha mikro kecil mendapatkan akses pemasaran yang lebih luas. Penelitian ini bertujuan menginisiasi model adopsi digital marketing yang ideal bagi pelaku usaha mikro kecil agar dapat mengembalikan kondisi ekonomi seperti semula. Metode penelitiannya adalah pendekatan kualitatif eksplorasi dengan menggunakan data primer yang diperoleh dari observasi dan wawancara. Teknik pengambilan sampel menggunakan purposive sampling dengan kriteria narasumber adalah pelaku usaha mikro kecil binaan Dinas Koperasi dan UKM Kota Semarang, Kota Surakarta, Kabupaten Grobogan, Kabupaten Pemalang, Kabupaten Purworejo. Alur analisis penelitian adalah pengumpulan data, reduksi data, penyajian data, dan penarikan simpulan. Hasil penelitian ini menunjukkan dua alternatif model solutif, yaitu pelatihan dan pengembangan startup serta pelatihan dan pengembangan scaleup. Urgensi penelitian ini memberikan inisiasi bagi pemerintah untuk melaksanakan pengelolaan program secara online single submission sehingga mampu meminimalisir kesalahan dan memantau perkembangan program. Model solutif ini diharapkan dapat menjadi role model yang berlandaskan pada ta'awun (mutual relation) bagi pemerintah provinsi lain dalam memberdayakan pelaku usaha mikro kecil menjadi lebih optimal berbasis teknologi tepat guna.

Kata kunci: kewirausahaan digital; pelaku usaha mikro kecil; pemasaran digital; pemberdayaan; pemulihan ekonomi

\section{PENDAHULUAN}

Pandemi Covid-19 mempercepat kemerosotan ekonomi yang belum pernah terjadi sebelumnya dan usaha kecil kemungkinan akan menanggung beban terberatnya. Pembatasan wajib dan jarak sosial memaksa banyak usaha kecil untuk menutup usaha mereka yang membuat jutaan orang kehilangan pekerjaan dan menurunkan penjualan. Bahkan ketika pemerintah mulai mencabut kebijakan Pembatasan Sosial Berskala Besar (PSBB), efek sisa pengangguran dan operasi bisnis yang terganggu akan semakin mempersulit pemulihan ekonomi usaha kecil. Menurut Thaha (2020), berbagai pelaku usaha menghadapi masalah yang berbeda dengan tingkat kerugian tertentu, seperti penurunan permintaan, gangguan rantai pasokan, pembatalan pesanan ekspor, kekurangan bahan baku, dan gangguan transportasi. Hilangnya permintaan dan pendapatan yang dramatis dan tiba-tiba untuk pelaku usaha mikro dan kecil sangat memengaruhi kemampuan kinerja pemasarannya. Selain itu, dari sisi konsumen pun mengalami kehilangan pendapatan, ketakutan akan penularan, dan meningkatnya ketidakpastian, yang akhirnya mengurangi pengeluaran dan konsumsi. Efek ini diperparah karena pekerja diberhentikan dan perusahaan tidak mampu membayar gaji. Pelaku usaha mikro dan kecil cenderung lebih rentan terhadap kebijakan pembatasan aktivitas di masyarakat, karena kinerja pemasaran mereka yang berbasis konvensional menjadi terhambat akibat kurangnya kemampuan dalam beradaptasi mengaplikasikan kecanggihan teknologi. Pelaku usaha mikro dan kecil harus berjuang dengan menghadapi banyak tantangan, seperti gangguan logistik, pembatasan mobilitas tenaga kerja, dan penurunan ketertiban pasar. Pelaku usaha mikro dan kecil di sektor jasa sangat terpukul karena permintaan yang menyusut. Setelah kebijakan pelonggaran pembatasan aktivitas diterapkan, akan berdampak pada pemulihan kinerja pemasaran dan tidak menutup kemungkinan efek tersebut dapat menjadi acuan pemerintah dalam merekonstruksi kinerja pemasaran pelaku usaha mikro dan kecil (Badan Pusat Statistik \& Dinas Koperasi dan UKM, 2020).

Pemerintah telah mengambil beberapa langkah untuk mengurangi kerusakan pada usaha kecil, tetapi langkah-langkah ini membebankan biaya besar pada pemerintah dan tergantung pada berapa lama pandemi berlangsung. Beberapa langkah ini mungkin tidak cukup untuk mempertahankan banyak usaha kecil dapat menjalankan usahanya. Pada praktiknya dalam kondisi normal, sekalipun pelaku usaha mikro kecil seringkali mengalami berbagai hambatan dan kesulitan, terlebih lagi dalam kondisi pasca pandemi Covid-19 di mana pelaku usaha mikro kecil berpotensi dalam penurunan daya beli, pangsa pasar yang sepi, dan kendala-kendala lain dalam proses produksi dan distribusi. Selanjutnya, diperlukan berbagai penyesuaian oleh unit bisnis dalam menjalankan usahanya agar mampu bertahan dari makro ekonomi 
yang tidak menentu, mencegah dari kebangkrutan, dan meningkatkan daya saingnya (Hardilawati, 2020).

Salah satu cara untuk memperbaiki lingkungan bagi usaha kecil selama dan setelah pandemi Covid19 adalah dengan membuat pengecualian peraturan untuk usaha kecil. Pengecualian ini dapat bersifat permanen atau tetap berlaku hanya sampai ekonomi pulih, dan dapat diterapkan di tingkat daerah maupun desa. Cara paling efektif untuk menerapkan pengecualian peraturan adalah dengan mengecualikan usaha kecil dari kelompok peraturan yang besar dan terdefinisi dengan baik, terutama yang usaha kecilnya bukan merupakan sumber masalah yang signifikan yang ingin dipecahkan oleh peraturan tersebut, karena usaha kecil tidak menciptakan masalah sejak awal, membebaskan usaha kecil tidak akan membebankan biaya besar pada masyarakat (Bahtiar \& Saragih, 2020). Selain itu, terjadinya pandemi juga mengubah perilaku pembelian konsumen yang semakin banyak menggunakan $e$-commerce sebagai alternatif solusi berbelanja. Pelaku usaha mikro kecil juga harus menyesuaikan diri dengan kondisi ini agar mampu bertahan di dalam industri dan meningkatkan daya saingnya, sehingga tidak mengalami kebangkrutan. Sistem pemasaran baru dengan memanfaatkan teknologi merupakan sebuah kendala baru bagi usaha mikro kecil dalam memasarkan produknya, karena berkaitan dengan pemahaman dan juga kemampuan penerapan teknologi tersebut (Pakpahan, 2020). E-marketing berada pada level stratejik sebagai motor dalam program peningkatan sistem pemasaran melalui kecanggihan teknologi yang dapat dimanfaatkan oleh usaha mikro kecil agar dapat terus bersaing di industri, karena mampu menekan biaya operasional pemasaran dan membantu usaha mikro kecil memperluas pangsa pasar melalui kemudahan akses data dan jangkauan pasar yang semakin luas pula. Dengan adanya alternatif solusi memanfaatkan kecanggihan teknologi, diharapkan mampu memberikan dampak signifikan terhadap kelangsungan usaha dari para pelaku usaha mikro kecil (Qashou \& Saleh, 2018).

Pemberdayaan merupakan suatu konsep yang berlaku bagi individu, organisasi, dan masyarakat. Dari proses tersebut, pemberdayaan bagi individu dapat berupa partisipasi dalam organisasi masyarakat, pada organisasi meliputi pengambilan keputusan bersama dan kepemimpinan bersama, serta pada masyarakat dapat berupa tindakan kolektif untuk mengakses pemerintah dan sumber daya masyarakat lainnya. Hasil pemberdayaan untuk individu termasuk situasi tertentu yang dirasakan, kontrol, dan keterampilan mobilisasi sumber daya; untuk organisasi termasuk pengembangan jaringan organisasi, pertumbuhan organisasi, dan pengaruh kebijakan; dan untuk masyarakat termasuk bukti pluralisme, keberadaan koalisi organisasi, dan sumber daya komunitas yang dapat diakses (Mentari, 2017). Dalam ilmu manajemen, konsep pemberdayaan didefinisikan sebagai gagasan individu memiliki kekuatan untuk menyelesaikan pekerjaan dengan cara yang efektif. Kemampuan ini diperoleh dari kondisi yang memungkinkan pelaku usaha mikro dan kecil untuk mencapai tujuan melalui kontrol pribadi dan kepentingan pengaruh sosial, serta kekuatan politik dan hak-hak hukum. Oleh karena itu, pemberdayaan dapat terjadi pada tiga tingkatan antara lain (1) di tingkat pribadi, pemberdayaan adalah pengalaman mendapatkan kontrol dalam kehidupan sehari-hari dan partisipasi masyarakat, (2) di tingkat kelompok kecil, pemberdayaan melibatkan pengalaman bersama serta analisis dan pengaruh kelompok terhadap upaya mereka, dan (3) di tingkat masyarakat, pemberdayaan berkisar pada pemanfaatan sumber daya dan strategi untuk meningkatkan kontrol masyarakat (Munib et al., 2020).

Kinerja pemasaran merupakan konsep untuk mengukur prestasi pasar suatu produk di mana setiap prestasi yang dihasilkan dari proses atau perilaku pelaku usaha mikro dan kecil mampu menghasilkan output yang baik sesuai harapan. Untuk mencapai kinerja yang baik, perlu dilakukan perencanaan strategis dengan mengidentifikasi faktor lingkungan eksternal dan internal agar mampu meminimalisir kesalahan. Kinerja juga merupakan wujud sejauh mana perencanaan strategis dilaksanakan, artinya kinerja pemasaran yang baik dihasilkan dari perencanaan strategis yang baik disertai dengan peningkatan sumber intensitas sehingga dapat mencapai hasil yang maksimal (Verma, 2021). Kinerja pemasaran dapat diukur dengan menggunakan pertumbuhan penjualan, pertumbuhan pelanggan, dan keberhasilan penetrasi produk. Pada dasarnya, tujuan didirikannya suatu usaha adalah untuk mendapatkan keuntungan yang sebesar-besarnya. Oleh karena itu perlu adanya kesinambungan dan peningkatan dalam kegiatan pemasaran yang berusaha memperoleh kebutuhan dan keinginan dengan cara menciptakan, menawarkan, dan mempertukarkan produk yang bernilai dengan pihak lain. Kinerja pemasaran juga bertujuan untuk meningkatkan keuntungan bagi pelaku usaha melalui aktivitas yang bersumber dari interaksi yang terjadi dengan konsumen melalui pemahaman, membangun komunikasi yang baik, dan menyampaikan nilai produk yang dihasilkan (Gao, 2020). 
Hasil penelitian Setiowati et al. (2015) menyatakan bahwa perlu untuk mendidik pemilik atau pengelola usaha mikro kecil tentang potensi keuntungan yang akan mereka peroleh dengan menerapkan kapabilitas adopsi pemasaran elektronik yang hemat biaya untuk bisnis mereka. Untuk meningkatkan daya saing usaha mikro kecil, pemerintah Indonesia memfasilitasi pelatihan usaha mikro kecil termasuk pelatihan e-marketing. Rao \& Rajeswari (2020) mengatakan bahwa kegiatan pemasaran meliputi komunikasi, koordinasi, dan manajemen organisasi. Penerapan e-marketing oleh usaha mikro kecil menemukan bahwa hanya sebagian kecil (kurang dari 10\%) UMKM yang terus mengadopsi e-marketing setelah mendapatkan pelatihan dari pemerintah. Alasan utama untuk setidaknya mengadopsi lebih lanjut adalah kurangnya kemampuan usaha mikro kecil untuk menyelaraskan bisnis dan teknologi informasi. E-marketing dinilai efektif diterapkan oleh usaha mikro kecil untuk memasarkan produknya. Salah satu daya saing yang harus dimiliki oleh usaha mikro kecil adalah penguasaan teknologi informasi.

Berdasarkan latar belakang permasalahan yang disampaikan, maka penelitian ini bertujuan untuk mengeksplorasi proses adopsi e-marketing sebagai penerapan implementasi usaha mikro kecil untuk melawan dampak bisnis pasca Covid-19. Selain itu, adanya dorongan dalam mengeksplorasi program pemasaran digital dan pembiayaan syariah sebagai upaya pelaku usaha mikro kecil bangkit pasca pandemi Covid-19. Hal yang perlu dipersiapkan adalah integrasi program dengan pemerintah dalam mempersiapkan program ini dengan ideal, mengingat akses teknologi juga menjadi salah satu hambatan terbesar bagi pelaku bisnis. Maka, penelitian ini berusaha untuk mengembangkan dan menyusun sebuah program yang ideal dalam adopsi program pemasaran digital pada pelaku usaha-usaha mikro kecil dalam rangka pemulihan kinerja pemasaran pasca pandemi Covid-19. Urgensi penelitian ini adalah mendukung program pemerintah dalam merekonstruksi kinerja pemasaran pelaku usaha mikro kecil yang terintegrasi dengan teknologi agar dapat dianalisis, dievaluasi, dan diperbaiki secara lebih komprehensif, sehingga di masa mendatang para pelaku usaha mikro kecil lebih adaptif dan tidak mengalami kesulitan beradaptasi pada kondisi industri yang berubah-ubah.

Penggunaan media sosial yang efektif dan efisien dinilai berdampak positif bagi operasional bisnis, karena potensi yang dimiliki dapat mengubah skema pemasaran usaha mikro kecil termasuk penyesuaian/ adaptasi, pemasaran hubungan pelanggan, akses ke pasar baru, kolaborasi bisnis-ke-bisnis, penciptaan bersama produk dengan pelanggan, dan peningkatan efisiensi (Afifah et al., 2018). Kumar et al. (2015) menyatakan bahwa dengan bantuan teknologi informasi, telah menciptakan peluang baru bagi perusahaan untuk mengadopsi alat pemasaran digital modern untuk mempromosikan produk mereka melalui beberapa saluran pemasaran. Pemasaran digital mengacu pada sikap baru dan keterlibatan realistis modern dengan pemasaran barang, jasa, informasi, dan bahkan ide melalui internet. Media promosi pada edisi pemasaran tradisional dapat dideskripsikan seperti iklan televisi, media cetak (koran, majalah, poster), dan radio yang memiliki biaya mahal dan sudah pasti tidak dapat dibeli oleh pelaku usaha mikro kecil untuk mengenalkan produknya apalagi memperoleh pangsa pasar, sedangkan pelaku usaha kelas besar memiliki anggaran pemasaran yang relatif besar dan dapat dengan mudah berinvestasi pada berbagai media promosi sesuai keinginan. Oleh karena itu, karakteristik pemasaran digital termasuk kemampuan untuk menargetkan pelanggan yang tepat, efisiensi biaya, dan kemudahan aksesibilitas, telah menarik banyak usaha mikro kecil untuk menggunakannya dalam melayani pelanggan. Strategi pemasaran digital mencakup banyak manfaat untuk menciptakan hubungan komunikasi antara perusahaan dan pelanggan mereka di lingkungan online. Selain itu, pemasaran digital membantu perusahaan untuk mempromosikan produk dan layanan mereka, menghasilkan penjualan, dan meningkatkan visibilitas produk dan layanan yang diiklankan.

Technology Acceptance Model/ Model penerimaan teknologi (TAM) berdasarkan teori tindakan beralasan. TAM dapat digunakan untuk menjelaskan dan memprediksi akseptabilitas suatu teknologi informasi, menganalisis dan mengeksplorasi faktor-faktor yang memengaruhi akseptabilitas suatu teknologi informasi tertentu. TAM menunjukkan bahwa persepsi kegunaan (PU) dan persepsi kemudahan penggunaan (PEOU) adalah dua faktor yang dapat memengaruhi sikap. Menurut TAM, niat perilaku memiliki efek positif dan substansial pada perilaku yang sebenarnya. TAM adalah salah satu model yang paling banyak digunakan untuk menjelaskan perilaku penerimaan pengguna. Model ini berpijak pada teori psikologi sosial pada umumnya dan Theory of Reasoned Action (TRA) pada khususnya. TRA menegaskan bahwa keyakinan memengaruhi sikap, yang mengarah pada niat dan karenanya menghasilkan perilaku. Kegunaan yang dirasakan (PU) dan kemudahan penggunaan yang dirasakan (PEOU) membentuk keyakinan pengguna akhir pada suatu teknologi, dan oleh karena itu memprediksi sikapnya terhadap teknologi, yang pada gilirannya memprediksi penerimaannya 
(Setiawan, 2017). Contoh topik terkait pemasaran yang menerapkan TAM adalah teknologi swalayan, adopsi media sosial, teknologi CRM seluler, alat otomatisasi tenaga penjualan, dan e-commerce. Kemudahan penggunaan dan kegunaan teknologi juga terkait dengan misalnya, evaluasi pascapenggunaan, niat mengunjungi kembali, dan sikap (Rao \& Rajeswari, 2020). Usaha mikro kecil di Indonesia masih berada pada tahap adopsi pemasaran digital yang lebih rendah karena beberapa faktor, seperti kurangnya dukungan manajemen puncak, kurangnya keterampilan staf, persepsi yang rendah tentang keamanan dan privasi, kurangnya kepercayaan, praktik hukum, kinerja situs yang lambat, dan kurangnya kesadaran di antara para pengambil keputusan. Selain itu, situs web negara lain memiliki masalah besar dalam hal desain, sebagian besar situs web menyesatkan dan informasi penting biasanya tidak ditampilkan. Oleh karena itu, hal ini tentunya akan berdampak negatif bagi pelanggan untuk membangun hubungan dengan perusahaan. Sesederhana informasi tersebut, keberadaan mereka akan menjadi penting bagi perusahaan untuk mempromosikan merek dan produk mereka (Mohan \& Ali, 2019).

Pemasaran digital mencakup banyak alat yang merupakan metode komunikasi penting bagi pelanggan dan perusahaan. Perusahaan bervariasi dalam mengadopsi alat tersebut, tergantung pada apa yang paling sesuai dengan tujuan dan model bisnis mereka. Pemasaran digital melalui email adalah salah satu alat umum yang ditawarkan. Pemasaran digital melalui email adalah alat penting dan hemat biaya yang memberikan informasi yang relevan kepada pelanggan tentang produk dan merek perusahaan. Di Indonesia, pemasaran email ditemukan sebagai alat pemasaran digital yang paling umum digunakan di kalangan usaha mikro kecil. Media sosial adalah alat lain yang memungkinkan pembuatan dan pertukaran konten buatan pengguna. Pelanggan mengadopsi media sosial untuk berkomunikasi, mencari produk atau merek, dan bertukar pikiran. Popularitas situs media sosial telah berkembang pesat dan telah menjadi tujuan utama orang Indonesia terhubung ke internet. Usia rata-rata pengguna Facebook dengan lebih dari satu juta pengguna adalah dari usia 18-34 tahun. Oleh karena itu, ini akan membuka peluang besar bagi banyak UKM untuk membidik dengan usia tersebut.

Adopsi pemasaran digital menghadapi banyak tantangan di sebagian besar perusahaan terutama UMK. Tantangan tersebut ditangkap dan ditunjukkan sebagai kurangnya dukungan manajemen yang biasanya tidak memprioritaskan pemasaran digital. Perusahaan mengadopsi inovasi baru hanya jika memberikan manfaat yang jauh lebih baik daripada yang sudah ada sebelumnya. Selanjutnya, pemahaman manajerial puncak tentang manfaat yang dirasakan dari teknologi baru meningkatkan kemungkinan alokasi sumber daya manajerial, keuangan, dan teknologi yang diperlukan untuk adopsi. Hubungan positif antara motivasi teknologi dan adopsi teknologi diperkuat dengan adanya manajemen yang menguntungkan. Pemilik bisnis dengan pengetahuan yang kuat tentang teknologi lebih mampu mengadopsi teknologi baru dan menerapkannya dengan cara yang memastikan pencapaian tujuan strategis (Hanum \& Sinarasri, 2017).

Isu-isu penting yang berdampak pada adopsi teknologi pemasaran oleh pemilik-manajer usaha kecil termasuk: (1) Berkaitan dengan peran yang sangat berpengaruh yang dimainkan oleh pemilik bahwa kompetensi pemilik di bidang visi, nilai, kemampuan teknis dan kontrol, ditambah dengan sejauh mana pelanggan, kolaborator, dan pesaing menggunakan internet dapat memengaruhi adopsi teknologi; (2) Ada kemungkinan adopsi teknologi yang lebih berhasil di mana pemilik menganggapnya sebagai penggerak bisnis dan dapat melihat manfaat jangka panjangnya. Manfaat situs web, melihatnya sebagai 'alat pemasaran penting' yang menyediakan akses ke pelanggan baru, membangun hubungan yang lebih kuat dengan pelanggan yang sudah ada, mengakses ceruk pasar, dan mengubah persepsi pelanggan tentang produk atau layanan perusahaan; (3) Kaitan antara orientasi pasar dan adopsi teknologi kurang jelas tentang peran yang dimainkan oleh teknologi dalam memungkinkan orientasi tersebut dalam usaha mikro kecil. Namun, kami mengakui bahwa hubungan antara orientasi pasar dan pengembangan proposisi nilai online adalah area yang memerlukan pemahaman yang lebih berkembang dari perspektif bisnis kecil; (4) Hambatan adopsi teknologi untuk pemasaran, termasuk faktor sumber daya (misalnya waktu dan uang) dan keterbatasan ini didokumentasikan dengan baik dalam literatur bisnis kecil. Hambatan potensial lebih lanjut adalah tantangan yang dihadapi usaha kecil dalam mengintegrasikan praktik pemasaran tradisional dengan peluang berbasis web baru dan biaya peluang di mana usaha kecil dapat melihat investasi dalam pemasaran online dengan mengorbankan pemasaran yang lebih tradisional; (5) Usaha kecil cenderung memilih pendekatan yang hanya melakukan daripada perencanaan formal. Logika efektif sebagai lensa untuk melihat teknologi untuk adopsi pemasaran sangat menarik dalam konteks media digital, di mana peluang untuk keterlibatan pelanggan secara 
signifikan lebih besar daripada melalui media yang lebih tradisional. Selain itu, keterlibatan ini sangat terukur, di mana hampir semua bentuk keterlibatan pelanggan online dapat dilacak dan dianalisis dan wawasan digunakan untuk memberi umpan balik ke dalam aktivitas pemasaran. Kontribusi logika yang efektif untuk bidang penggunaan teknologi untuk pemasaran usaha mikro kecil dianalisis kemudian disajikan; serta (6) Transisi dari fokus khusus situs web ke berbagai teknologi yang diperluas seperti aplikasi seluler, jejaring sosial, dan analitik telah menciptakan lanskap yang kompleks yang semakin menantang bagi pemilik-manajer usaha mikro kecil untuk menavigasi.

UMKM adalah unit usaha produktif yang berdiri sendiri, yang dilakukan oleh orang perorangan atau badan usaha di semua sektor ekonomi. Pada prinsipnya, pembedaan antara Usaha Mikro (UMi), Usaha Kecil (UK), Usaha Menengah (UM), dan Usaha Besar (UB) umumnya didasarkan pada nilai aset awal (tidak termasuk tanah dan bangunan), omzet rata-rata pertahun, atau jumlah pekerja tetap (Tambunan, 2019). Di Indonesia, definisi UMKM diatur berdasarkan Undang-undang Republik Indonesia Nomor 20 Tahun 2008 sebagai berikut.

Tabel 1. Klasifikasi UMKM

\begin{tabular}{lll}
\hline Ukuran usaha & \multicolumn{1}{c}{ Total asset } & \multicolumn{1}{c}{ Omzet } \\
\hline Mikro & < 50 Juta Rupiah & $<$ 300 Juta Rupiah \\
Kecil & 50-500 Juta Rupiah & $<3$ Miliar Rupiah \\
Menengah & 500 Juta-10 Miliar Rupiah & 2,5-50 Miliar Rupiah \\
\hline
\end{tabular}

Sumber: UU No. 20 Tahun 2008 (2008)

Inklusi keuangan memperluas basis sumber daya sistem keuangan dengan mengembangkan budaya menabung di antara sebagian besar penduduk pedesaan dan memainkan perannya sendiri dalam proses pembangunan ekonomi. Inklusi keuangan memberikan layanan keuangan kepada pelanggan melalui sistem terpadu dengan biaya yang terjangkau dan mudah tersedia kapan pun dan di manapun. Layanan keuangan disampaikan, terutama oleh bank bersama dengan lembaga keuangan lainnya seperti kantor pos, perusahaan asuransi, pialang, dana investasi, dan sebagainya yang secara kolektif dikenal sebagai sektor keuangan. Perkembangan sektor keuangan ini menurunkan biaya informasi dan transaksi yang memainkan peran penting dalam memobilisasi tabungan, menyalurkan kredit, memfasilitasi pembayaran, manajemen risiko, dan lain-lain untuk meningkatkan pertumbuhan ekonomi yang mengarah pada pengurangan kemiskinan. Pemerintah, melalui Badan Perencanaan Pembangunan Daerah, Bidang Penelitian, dan Pengembangan Ekonomi, menginisiasikan program bantuan pembiayaan kepada pelaku usaha mikro dan kecil yang unggul berbasis syariah (akad Murabahah) dengan melakukan kerja sama melalui nota kesepahaman dengan beberapa instansi lainnya, seperti beberapa Bank Pembiayaan Rakyat Syariah, Badan Amil Zakat, Masyarakat Ekonomi Syariah (MES), Dinas Koperasi dan Usaha Mikro, perusahaan telekomunikasi, agen branchless banking, serta lembaga financial technology (Fitriana et al., 2019).

\section{METODE}

Jenis penelitian ini menggunakan metode kualitatif eksploratif. Metode ini digunakan untuk mengidentifikasi proses adopsi e-marketing pada pelaku usaha mikro kecil, guna melawan dampak bisnis Pandemi Covid-19. Jenis data adalah data primer yang merupakan jawaban langsung dari informan mengenai proses adopsi e-marketing. Teknik pengumpulan data menggunakan metode wawancara. Desain pengambilan sampel menggunakan non-probability sampling (snowball), suatu metode yang digunakan untuk mengidentifikasi, memilih, dan mengambil sampel dalam suatu jaringan atau rantai hubungan yang menerus (Igwenagu, 2016). Teknik analisis program adopsi e-marketing dilakukan melalui pengumpulan data, reduksi data, penyajian data, dan penarikan simpulan, karena metode ini mampu menjelaskan, menilai, dan memvisualisasikan pemodelan pemberdayaan pada sektor usaha mikro dan kecil unggulan berbasis syariah secara rasional, komprehensif, dan lebih optimal.

a. Teknik observasi langsung, peneliti secara langsung mengamati keadaan objek yang diteliti, yaitu praktik pelaku usaha mikro dan kecil.

b. Teknik wawancara, dilakukan secara mendalam (depth interview) baik dari pihak pengelola program. 
c. Teknik observasi dan kepustakaan, yang diperoleh dari beberapa laporan yang dikeluarkan oleh instansi yang terlibat dalam pelaksanaan program.

Melalui program ini, terdapat integrasi dengan stakeholder yang terkait berbasis syariah untuk menentukan arah kebijakan memberikan kesempatan akses usaha mikro dan kecil potensial dalam pembiayaan syariah. Program ini digunakan untuk meningkatkan kapasitas dan elijibilitas dari usaha mikro dan kecil dalam mengakses ke lembaga keuangan serta mendorong lembaga keuangan untuk dapat memberikan layanan pembiayaan kepada usaha mikro dan kecil, sehingga sasaran akhir adalah tercapainya kemandirian dan pertumbuhan usaha mikro dan kecil yang mampu berdaya saing, mandiri, sejahtera, dan berbudaya berlandaskan pada nilai-nilai religiusitas. Daftar pertanyaan wawancara yang diajukan antara lain:

a. Bagaimana cara Anda mencari tahu tentang e-marketing?

b. Apa yang Anda lakukan setelah mendapat cukup informasi terkait e-marketing? Apakah Anda langsung tertarik untuk mengadopsi?

c. Apa yang membuat Anda tertarik dan kemudian memutuskan untuk mengadopsi e-marketing?

d. Bagaimana tahapan pembuatan e-marketing? Apakah dalam tahap ini, Anda membuat sendiri atau menggunakan vendor?

e. Apa saja manfaat yang didapat setelah mengadopsi e-marketing?

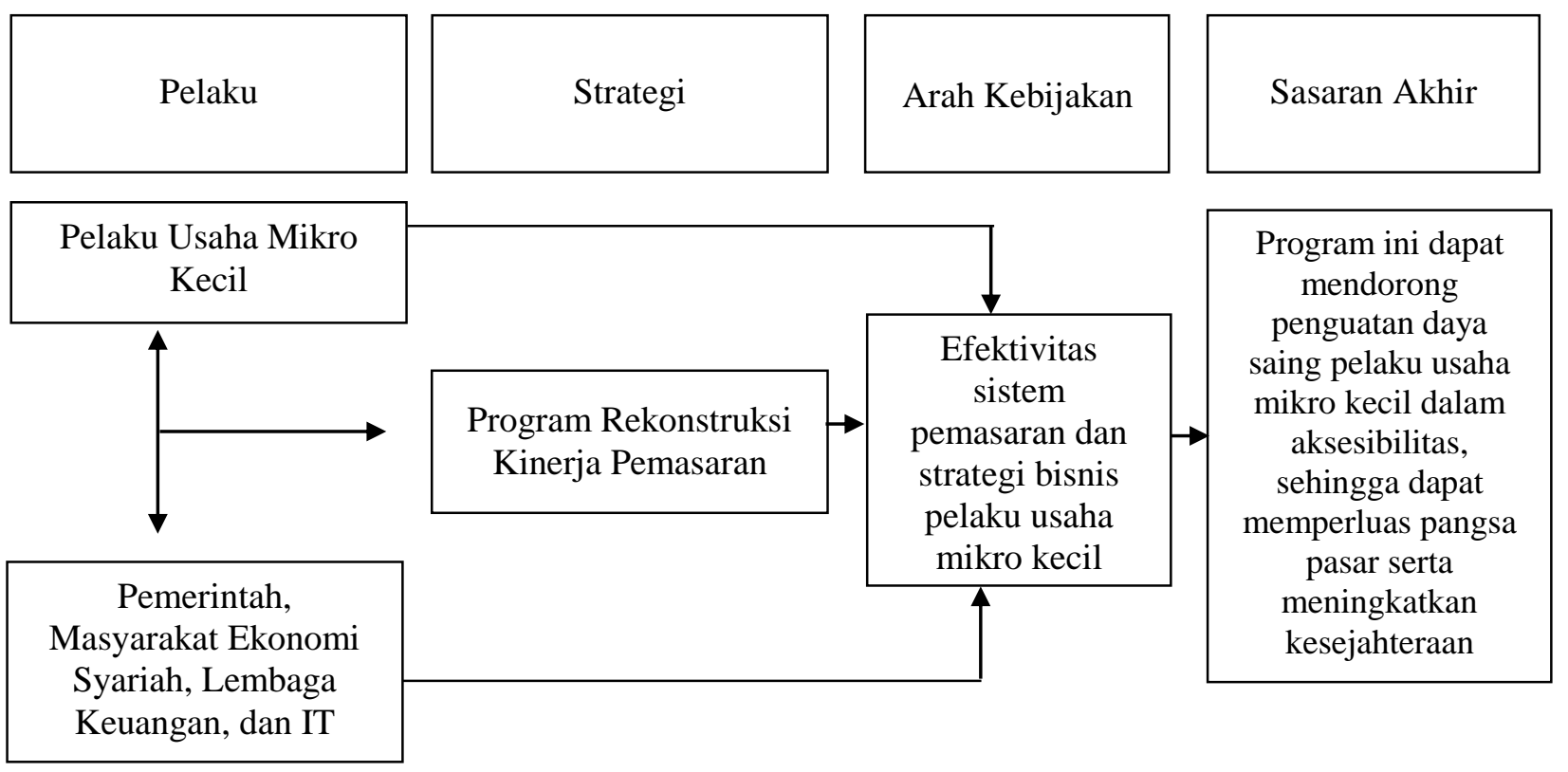

Gambar 1. Rekonstruksi pemulihan kinerja pemasaran usaha mikro dan kecil

Sumber: Kajian literatur tim peneliti (2021)

\section{HASIL DAN PEMBAHASAN}

Program rekonstruksi pemulihan kinerja pemasaran ini harus melalui perjalanan yang panjang, sehingga ini menjadi tantangan bagi pemerintah melalui Dinas Koperasi dan Usaha Mikro agar terselenggara secara optimal. Selain itu inisiasi program bantuan pembiayaan kepada pelaku usaha mikro dan kecil yang unggul berbasis syariah (akad Murabahah) dengan melakukan kerja sama melalui nota kesepahaman dengan beberapa instansi lainnya, seperti Bank Pembiayaan Rakyat Syariah, Badan Amil Zakat, Masyarakat Ekonomi Syariah (MES), Dinas Koperasi dan Usaha Mikro, perusahaan telekomunikasi, agen branchless banking, serta lembaga financial technology juga mendorong kapasitas produksi dan kemampuan permodalan para pelaku usaha mikro kecil. Tahapan demi tahapan dipersiapkan dengan komprehensif agar pemodelan dapat dicapai dengan ideal dan aplikatif, sehingga diharapkan program ini bisa diterapkan hingga ke seluruh provinsi di Indonesia. 
Tabel 2. Permasalahan yang dihadapi pelaku usaha mikro kecil

\begin{tabular}{lll}
\hline \multicolumn{1}{c}{ Aspek Internal } & \multicolumn{1}{c}{ Aspek Eksternal } \\
\hline - Lemahnya dalam melakukan inovasi & - Ancaman dari produk impor yang serupa \\
usaha & - Rendahnya kontribusi pihak eksternal dalam \\
- Diseconomies of scale yang dipengaruhi & & mendukung pengembangan pelaku usaha \\
oleh kapasitas produksi yang terbatas, & mikro kecil \\
sehingga harga jual relatif tinggi & - Kesulitan dalam melakukan ekspansi pasar \\
- Terbatasnya pemodalan yang dimiliki & - Terbatasnya proses pembiayaan lembaga \\
- Rendahnya kemampuan dari SDM, & keuangan formal, karena literasi keuangan \\
$\begin{array}{l}\text { yang berpengaruh pada rendahnya } \\
\text { kualitas dari produk yang belum optimal }\end{array}$ & - $\begin{array}{l}\text { Reng rendah } \\
\text { - Rendahnya kondisi infrastruktur yang } \\
\text { teknologi }\end{array}$ & $\begin{array}{l}\text { mengakibatkan tingginya biaya distribusi } \\
\text { dan harga jual }\end{array}$ \\
\hline
\end{tabular}

Sumber: Analisis tim peneliti (2021)

Proses pengadopsian program pemulihan kinerja pemasaran pelaku usaha mikro kecil ini harus melalui perjalanan yang panjang, sehingga ini menjadi tantangan bagi pemerintah melalui Dinas Koperasi dan Usaha Mikro agar terselenggara secara optimal. Tahapan demi tahapan dipersiapkan dengan komprehensif agar pemodelan dapat dicapai dengan ideal dan aplikatif, sehingga diharapkan program ini bisa diterapkan hingga ke seluruh provinsi di Indonesia. Terdapat lima tahapan yang secara sistematis harus dilalui sebagai media pada proses pengadopsian program pemulihan kinerja pemasaran antara lain (Müller, 2019):

a. Fase Pendidikan Pemahaman

Fase ini merupakan proses pembaharuan dari ilmu pengetahuan yang dimiliki oleh pelaku usaha mikro kecil, sehingga secara tidak langsung melakukan pembaharuan dalam aspek internal dan eksternal, sehingga menjadi solusi dari permasalahan yang dihadapi. Penekanan pada tahapan ini adalah pencarian dan pemrosesan informasi yang dibutuhkan dalam proses pengadopsian program. Penguasaan kedua aspek ini dapat meminimalisir ketidakpastian pada proses pengambilan keputusan dalam melakukan pengadopsiannya.

b. Fase Inisiasi Pemahaman

Fase ini merupakan persiapan awal dalam proses pengadopsian dalam program pemulihan kinerja pemasaran pelaku usaha mikro kecil. Faktor internal menunjukkan self awareness dalam proses pengadopsian, di mana keseluruhan informasi yang akan dipergunakan dalam proses pengadopsian, seperti kesiapan teknologi informasi, kualitas dan kuantitas usaha, serta kemampuan dalam pengelolaan keuangan, sedangkan faktor eksternal di antaranya ketersediaan kebijakan pemerintah, potensi pasar (pangsa pasar), dan daya saing industri. Pemilihan informasi yang tepat guna dapat memberikan masukan bagaimana proses pengadopsian ini dapat dilakukan guna melancarkan aktivitas usaha, khususnya dalam melakukan pemasaran digital berbasis media katalog elektronik.

c. Fase Pengambilan Keputusan Adopsi

Fase ini merupakan proses pengambilan keputusan yang akan diambil bagi pelaku usaha mikro kecil dengan berbagai dasar pertimbangan, antara lain kemudahan pemasaran produk, kemudahan mengakses data yang mudah, serta memperluas pangsa pasar. Harapannya, semakin besar kebermanfataan yang diperoleh dari adopsi program tersebut, menjadi semakin banyak pelaku usaha yang dapat melaksanakan. Pelaku usaha mikro kecil yang mengadopsi program ini berguna untuk dalam melakukan pemasaran digital, dapat bertahan dalam kondisi perekonomian yang sedang lesu akibat pandemi Covid-19.

d. Fase Hasil Adopsi

Fase ini merupakan hasil yang dapat diperoleh jika pelaku usaha mikro kecil mengadopsi program tersebut. Salah satu keunggulan yang ditawarkan dari adanya program ini adalah transformasi dari pengelolaan secara konvensional menjadi digital, sehingga dapat mengatasi kendala pengelolaan dengan biaya adopsi yang tinggi. Kemudahan dalam melakukan pencarian produk yang diinginkan melalui jaringan internet menjadi nilai tambah dari program tersebut, sehingga konsumen hanya perlu memasukkan kata kunci produk usahanya pada halaman pencarian. Hal ini dipengaruhi 
karena adanya perluasan pangsa pasar, peningkatan pangsa pasar, dan peningkatan kepercayaan pelanggan.

e. Fase Tindak Lanjut

Fase ini berisikan sebagai bentuk evaluasi adopsi program, sekaligus penyesuaian rancangan optimalisasi adopsi program yang dilaksanakan oleh pelaku usaha yang dapat menjalankan operasionalnya dengan pembaharuan teknologi digital agar dapat meningkatkan jumlah pesanan, media promosi yang efektif, dan kemudahan dalam menjaring konsumen bahkan hingga luar negeri. Oleh karena itu, pelaku usaha mikro kecil mampu bertahan dalam kondisi perekonomian yang sedang lesu akibat pandemi Covid-19.

Model rekonstruksi pada Gambar 2 disusun berdasarkan KPI berbasis web generik agar lebih efektif dan sesuai dengan industri digital, seperti tingkat konversi, di mana proporsi pengunjung atau pembeli yang melanjutkan untuk melakukan tindakan seperti berlangganan yang secara alami semakin tinggi tingkat konversi, maka lebih banyak pengunjung atau pembeli serta semakin baik kinerja pemasaran; new vs returning visitors di mana proporsi pengunjung atau pembeli yang sudah ada semakin loyal serta mengajak atau memengaruhi calon pembeli lainnya agar mau membeli; bounce rate merupakan tingkat pembelian produk pada usaha yang harus diamati pengelola sehingga dapat menganalisis perkembangan usaha dan kinerja pemasarannya; abandonment rate adalah tingkat pembatalan pembelian produk yang juga harus diamati oleh pengelola agar selalu melakukan inovasi dan pembaharuan sesuai dengan level usahanya sehingga pelanggan selalu loyal terhadap usaha; serta cost per conversion merupakan biaya per konversi yang pada dasarnya adalah perhitungan total biaya kampanye yang dibutuhkan oleh usaha tersebut saat melakukan penetrasi pasar, baik melalui media sosial ataupun lainnya. Key Performance Indicator (KPI) harus menjadi hal yang paling penting dalam mengukur keberhasilan situs web perusahaan. KPI dapat berupa hitungan atau rasio. Sementara, hitungan dasar dan rasio dapat digunakan oleh semua jenis situs web. KPI diintegrasikan dengan strategi bisnis dan kumpulan KPI yang tepat biasanya berbeda di antara lokasi dan jenis proses. Perspektif pengukuran kinerja pemasaran menyatakan bahwa memilih KPI yang tepat sangat penting untuk memantau kinerja organisasi secara efektif dan memungkinkan organisasi membuat keputusan berdasarkan informasi untuk perbaikan berkelanjutan (Sugandini et al., 2019).

Pengukuran keberhasilan KPI tersebut diukur menggunakan engagement dari platform digital yang digunakan oleh pelaku usaha, seperti Facebook ataupun Instagram, sehingga progress kinerja pemasaran dapat ditinjau secara lebih intens dan berkala. Hal ini dikarenakan platform digital menawarkan banyak peluang bagi keterlibatan konsumen dalam membangun kesadaran merek. Platform digital akan lebih menarik bagi pelaku usaha, karena sifat yang saling berhubungan antara pelaku usaha dan konsumen secara online dengan kecepatan informasi yang melintasi jaringan. Kuncinya adalah platform digital berisikan orang-orang yang berinteraksi dan bertukar informasi pada konten web yang berpikiran sama. Pelanggan online tertarik pada sesuatu yang dianggap menyenangkan, informatif, dan unik. Pelaku usaha dapat memiliki lebih banyak pengetahuan tentang pelanggannya, terkait hal yang disukai dan di mana lingkungan bergaulnya. Pelaku usaha perlu selalu terlibat dalam platform digital untuk mengenal pelanggan dengan baik. Namun, akan lebih baik jika pelaku usaha mem-posting tentang mengapa perusahaan adalah yang terbaik dan harus bisa menghormati komunitas online (Sugandini et al., 2019).

Multiplier effect yang ditimbulkan dari pandemi Covid-19 berimbas kepada kinerja pemasaran usaha mikro kecil di Indonesia, seperti jumlah pelanggan, pendapatan, keuntungan, ataupun kapasitas produksi. Oleh karena itu, keberhasilan program pemberdayaan ini akan sangat tergantung kepada komitmen para stakeholder dalam melaksanakan program. Pada era sekarang, berbagai kebutuhan dari operasional pelaku usaha mikro kecil membutuhkan dukungan teknologi informasi dan dunia digital agar menjadi lebih efektif dan efisien dalam melakukan setiap traksaksi, sehingga diperlukan strategi yang tepat guna, seperti komitmen dalam melakukan peningkatan investasi dalam pengembangan digital skills yang dilakukan pelaku usaha mikro kecil, perlu melakukan implementasi prototype teknologi baru maka diperlukan learning by doing, serta menggali bentuk kolaborasi dengan dunia industri, akademisi, serta masyarakat dalam adopsi program pemasaran digital kepada pelaku usaha mikro kecil. Pemetaan manfaat dan biaya, baik sosial dan ekonomi, dalam proses pengadopsian digitalisasi dan pemberdayaan pelaku usaha mikro kecil, menjadikan salah satu langkah yang strategis untuk penguatan ekonomi berbasis umat. Terdapat dua kategori dalam program pemulihan ini, yaitu pelatihan startup yang diperuntukkan untuk usaha mikro kecil yang belum memiliki usia kurang dari setahun serta pelatihan scaleup yang dibutuhkan untuk usaha yang sudah berjalan minimal selama tiga tahun. Sehingga, 
program ini bukan hanya ditujukan pada yang sudah berjalan saja, namun berlaku juga bagi yang belum berjalan. Selanjutnya, akan dilaksanakan program pendampingan usaha hingga bantuan pembiayaan.

\begin{tabular}{|c|c|}
\hline $\begin{array}{l}\text { Tahap } 1 \\
\text { Start up Business } \\
\text { (Bisnis Rintisan) }\end{array}$ & $\begin{array}{c}\text { Tahap } 2 \\
\text { Unorganized Business } \\
\text { (Bisnis Belum Terorganisir) }\end{array}$ \\
\hline $\begin{array}{ll}\text { Karakteristik: } \\
\text { - } & \text { Operasional unit bisnis baru } \\
& \text { berjalan dua tahun. } \\
\text { - } & \text { Pengelompokkan unit bisnis } \\
& \text { masuk pada kategori skala } \\
& \text { mikro. } \\
\text { - } & \text { Unit bisnis memiliki } \\
\text { kekayaan bersih sebesar Rp } \\
50 \text { juta dan omzet yang } \\
\text { diterima Rp } 300 \text { juta per } \\
\text { tahunnya. }\end{array}$ & 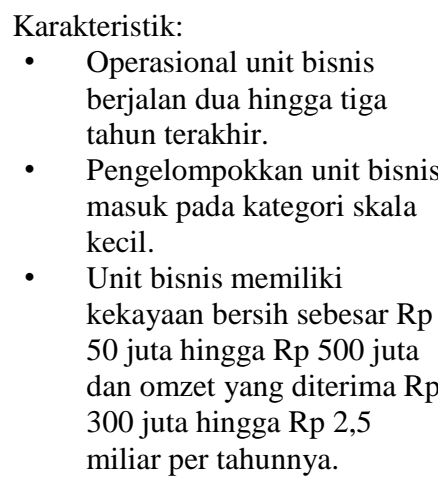 \\
\hline $\begin{array}{l}\text { Tahap } 4 \\
\text { Growing and Developing Business } \\
\text { (Bisnis Tumbuh Dan Berkembang) }\end{array}$ & $\begin{array}{c}\text { Tahap } 5 \\
\text { Capable in Independenly } \\
\text { (Bisnis Mandiri) }\end{array}$ \\
\hline $\begin{array}{l}\text { Karakteristik: } \\
\text { - } \quad \text { Operasional unit bisnis } \\
\text { berjalan lima tahun terakhir. } \\
\text { - } \\
\text { Pengelompokkan unit bisnis } \\
\text { masuk pada kategori skala } \\
\text { besar. } \\
\text { Unit bisnis memiliki kekayaan } \\
\text { bersih sebesar lebih dari Rp } 10 \\
\text { miliar dan omzet yang } \\
\text { diterima lebih dari Rp } 50 \\
\text { miliar per tahunnya. }\end{array}$ & $\begin{array}{l}\text { Karakteristik: } \\
\text { Sudah berkontribusi secara penuh } \\
\text { kepada operasional dan fasilitas } \\
\text { yang dibutuhkan, termasuk } \\
\text { berkontribusi secara sosial pada } \\
\text { pembangunan ekonomi skala } \\
\text { nasional. }\end{array}$ \\
\hline
\end{tabular}

\begin{tabular}{|c|}
\hline $\begin{array}{c}\text { Tahap } 3 \\
\text { Survive and Stable Business } \\
\text { (Bisnis Stabil dan Dapat Bertahan) }\end{array}$ \\
\hline $\begin{array}{ll}\text { Karakteristik: } \\
\text { - } & \text { Operasional unit bisnis } \\
& \text { berjalan tiga hingga lima } \\
& \text { tahun terakhir. } \\
\text { - } & \text { Pengelompokkan unit bisnis } \\
\text { masuk pada kategori skala } \\
\text { menengah. } \\
\text { Unit bisnis memiliki } \\
\text { kekayaan bersih sebesar Rp } \\
\text { 500 juta hingga Rp } 10 \text { miliar } \\
\text { dan omzet yang diterima Rp } \\
2,5 \text { miliar hingga Rp 50 } \\
\text { miliar per tahunnya. }\end{array}$ \\
\hline
\end{tabular}

Gambar 2. Model rekonstruksi pemulihan kinerja pemasaran usaha mikro kecil

Sumber: Analisi tim peneliti (2021)

\section{SIMPULAN DAN SARAN}

Hasil penelitian ini dapat memberikan konstribusi dalam pengembangan ilmu manajemen pemasaran berbasis teknologi. Bagi pengusaha, penelitian ini dapat digunakan sebagai pertimbangan untuk menentukan kebijakan dalam proses pengadopsian e-marketing, sehingga nantinya dapat berjalan dengan lancar, dapat mempermudah pengusaha dalam menjalankan usaha, serta mampu membantu pengusaha usaha mikro kecil meningkatkan daya saing maupun eksistensi di dunia usaha. Bagi pemerintah, penelitian ini dapat dijadikan sebagai bahan kajian maupun gambaran tentang keadaan, sehingga pemerintah mampu menentukan arah kebijakan maupun merancang program pelatihan terhadap pengusaha untuk peningkatan daya saing usaha mikro kecil melalui pengembangan adopsi $e$ marketing.

Program ini diharapkan dapat menjadi role model yang berlandaskan pada ta'awun mutual relation, sehingga proses pemberdayaan umat menjadi optimal serta didukung oleh pemanfataan teknologi tepat guna. Terdapat dua kategori dalam program ini, yaitu pelatihan startup yang diperuntukkan untuk pelaku usaha mikro kecil yang belum memiliki bisnis serta pelatihan scaleup yang dibutuhkan untuk unit bisnis yang sudah berjalan. Pemerintah dapat melaksanakan pengelolaan program ini secara online single submission, sehingga mampu meminimalisir kesalahan penerapan yang dilakukan oleh pihak-pihak yang terlibat. Di samping itu, sistem online ini memberikan peluang bagi pemerintah untuk memantau kemajuan mitra program dan menunjukkan secara transparan proses pemberdayaan bagi peningkatan 
perekonomian Indonesia. Keterbatasan penelitian ini adalah tidak semua pelaku usaha mikro kecil yang dapat diorganisir dengan baik karena data pemerintah yang kurang lengkap serta keterbatasan infrastruktur yang mendukung program tersebut.

\section{REFERENSI}

Afifah, A. N., Najib, M., Sarma, M., \& Leong, Y. C. (2018). Digital marketing adoption and the influences towards business successes of MSMEs creative sector in Indonesia and Malaysia. Jurnal Aplikasi Manajemen, 16(3), 377-386. https://doi.org/10.21776/ub.jam.2018.016.03.01

Badan Pusat Statistik \& Dinas Koperasi dan UKM. (2020). Koperasi dan UMKM terdampak pandemi Covid 19. https://www.pikiran-rakyat.com/ekonomi/pr-01379615/1785-koperasi-dan-163713umkm-terdampak-pandemi-covid-19

Bahtiar, R. A., \& Saragih, J. P. (2020). Dampak Covid-19 terhadap perlambatan ekonomi sektor UMKM. Jurnal Singkat, 12(6), 19-24. https://berkas.dpr.go.id/puslit/files/info_singkat/Info\%20Singkat-XII-6-II-P3DI-Maret-20201982.pdf

Fitriana, W., Rustiadi, E., Fauzi, A., \& Anggraeni, L. (2019). Penguatan inklusi keuangan pada industri kreatif berskala mikro kecil di Sumatra Barat. Jurnal Ekonomi dan Pembangunan Indonesia, 18(2), 140-153. https://doi.org/10.21002/jepi.v0i0.1112

Gao, Y. (2020). Measuring marketing performance: A review and a framework. The Marketing Review, 10(1), 25-40. https://doi.org/10.1362/146934710x488924

Hanum, A. N., \& Sinarasri, A. (2017). Analisis faktor-faktor yang mempengaruhi adopsi e-commerce dan pengaruhnya terhadap kinerja UMKM (Studi kasus UMKM di wilayah Kota Semarang). Jurnal Maksimum, 7(1), 1-15. https://doi.org/10.26714/mki.v7i1.3198

Hardilawati, W. L. (2020). The survival strategy of SMEs during the Covid-19 pandemic. Jurnal Akuntansi dan Ekonomika, 10(1), 89-98. https://doi.org/10.37859/jae.v10i1.1934

Igwenagu, C. (2016). Fundamentals of Research Methodology and Data Collection. LAP Lambert Academic Publishing. https://www.researchgate.net/publication/303381524_Fundamentals_of_research_methodology _and_data_collection

Kumar, P., Kumar, V., \& Mishra, J. M. (2015). A prospective study on online marketing of small and medium enterprises (SMEs) of services sector in India. International Journal of Applied Research, 1(9), 910-914. https://doi.org/10.13140/RG.2.1.1969.8329

Mentari, D. (2017). Pemberdayaan masyarakat sebagai terobosan dalam berwirausaha untuk memanfaatkan sumber daya alam. Jurnal Pemberdayaan, 1(1), 84-88. https://doi.org/10.12928/jp.v1i1.318

Mohan, V., \& Ali, S. (2019). Challenges faced by Indian MSMES in adoption of internet marketing and e-commerce. Academy of Marketing Studies Journal, 23(1), 1-9. https://www.abacademies.org/articles/Challenges-faced-\%20by-indian-msmes-in-adoption-ofinternet-marketing-and-e-commerce-1528-2678-23-1-188.pdf

Müller, J. M. (2019). Business model innovation in small-and medium-sized enterprises: Strategies for industry 4.0 providers and users. Journal of Manufacturing Technology Management. 30(8), 1127-1142. https://doi.org/10.1108/JMTM-01-2018-0008.

Munib, A., Viphindrartin, S., Saleh, M., Somaji, R. P., Jember, U. N., \& Java, E. (2020). Economic empowerment of communities around Islamic boarding school. International Journal of Advanced Science and Technology, 29(7), 5343-5349. http://repository.unej.ac.id/bitstream/handle/123456789/99608/F.\%20EB_Jurnal_Sebastiana\%2 0V_Effectiveness $\% 20$ of $\% 20$ the $\% 20$ Monetary.pdf? sequence $=1 \&$ isAllowed $=y$

Pakpahan, A. K. (2020). Covid-19 dan implikasi bagi usaha mikro, kecil, dan menengah. JIHI: Jurnal Ilmu Hubungan Internasional, 20(4), https://doi.org/https://doi.org/10.26593/jihi.v0i0.3870.59-64

Qashou, A., \& Saleh, Y. (2018). E-marketing implementation in small and medium-sized restaurants in Palestine. Arab Economic and Business Journal, 13(2), 93-110. https://doi.org/10.1016/j.aebj.2018.07.001

Rao, V. D. M., \& Rajeswari. (2020). Adoption of digital marketing practices in micro small medium 
Jurnal Manajemen Maranatha @ Vol. 21 Nomor 1, November (2021)

enterprises for inclusive growth. International Journal of Recent Technology and Engineering, 8(6), 1239-1244. https://doi.org/10.35940/ijrte.f7539.038620

Setiawan, A. (2017). Penerapan modifikasi Technology Acceptance Model (TAM) dalam e-business. Jurnal Manajemen dan Pemasaran Jasa, 10(2), 171-186. https://doi.org/10.25105/jmpj.v10i2.2277

Setiowati, R., Hartoyo, H., Daryanto, H. K., \& Arifin, B. (2015). Understanding ICT adoption determinants among Indonesian SMEs in fashion subsector. International Research Journal of Business Studies, 8(1), 47-57. https://doi.org/10.21632/irjbs.8.1.78.47-57

Sugandini, D., Effendi, M.., Istanto, Y., Arundati, R., \& Rahmawati, E. (2019). Pemasaran digital: Adopsi media sosial pada UMKM. Zahir Publishing

Tambunan, T. (2019). Recent evidence of the development of micro, small, and medium enterprises in Indonesia. Journal of Global Entrepreneurship Research, 9(18), 1-15. https://doi.org/10.1186/s40497-018-0140-4

Thaha, A. F. (2020). Dampak Covid-19 terhadap UMKM di Indonesia. Jurnal Brand, 2(1), 147-153. https://ejournals.umma.ac.id/index.php/brand/article/view/605/441

Undang-Undang Republik Indonesia Nomor 20 Tahun 2008. (2008). Tentang usaha mikro, kecil, dan menengah

Verma, M. K. (2021). Impact of COVID-19 on small and medium enterprises. Social Science Learning Education Journal, 6(5), 468-479. https://doi.org/10.15520/sslej.v6i05.2784 